$$
31.072: 631 \cdot 46: 534 \cdot 4 \cdot 7 \cdot 2
$$

\title{
BREAKDOWN OF FOREST LITTER IN RELATION TO ENVIRONMENTAL FACTORS
} by MARTIN WITKAMP * and J. VAN DER DRIFT

Institute for Biological Field Research, Arnhem, the Netherlands

\section{INTRODUCTION}

The rate of litter decay in forests has a pronounced effect on the availability of nutrients for tree growth. In extreme cases litter may be broken down and incorporated in the mineral soil within a year (mull) or it may accumulate for many years on top of the mineral substrate (mor) thus tying up nutrients. Various factors such as geology, topography, climate, soil microflora and fauna, vegetation and leaf properties $(\mathrm{pH}$, buffering capacity, mineral composition, tanning substances, $\mathrm{N}$ content or $\mathrm{C} / \mathrm{N}$ ) have been thought to control the formation of mull and mor. These factors have been reviewed and evaluated by Handley ${ }^{5}$.

In the present work, which was part of a research program on the rate and mechanism of cycling of matter in forest systems, litter production and breakdown in mull and mor in different seasons and years were compared. The results were related to differences in soil moisture, temperature, microbial population, litter feeding fauna, rates of breakdown of the main leaf components (cellulose and lignified tissue), and the soil concentration of $\mathrm{CO}_{2}$, the main product of litter decomposition.

\section{MATERIALS AND METHODS}

The forest studied has been described previously in detail 710 . It was a stand of slash oak, last cut about 1940 , locally mixed with birch, alder, and

* Prcsent address Ecology Section, Health Physics Division, Oak Ridge National Laboratory, Oak Ridge, Tennessee, U.S.A. 
poplar, 6.5 to $10.5 \mathrm{~m}$ high, $100 \%$ cover, timber 1 to $3 \mathrm{~m}^{3} / 100 \mathrm{~m}^{2}, 27 \mathrm{~km}$ ENE of Arnhem, Netherlands.

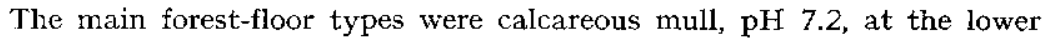
parts of the area and mor, $\mathrm{pH} 3.3$, at the higher parts. Both are on deep sand to loamy sand with lime in the lowest area.

The understory on the mor area was a Querceto-Betuletum Tx. 1930, 5 to $15 \%$ cover, under a canopy of $92 \%$ oak (Quercus robur L.) and $8 \%$ birch (Betula verrucosa Ehrh.). On the calcareous mull area there was a PrunetoFraxinetum Oberdorfer 1953,70 to $100 \%$ cover, under $28 \%$ oak, $36 \%$ birch, 19\% alder (Alnus glutinosa (L.) Gaertn.) and 17\% poplar (Populus tremula I.)

Litter production from trees and shrubs was measured by periodic littes collections from six bags of cheese cloth with a round opening of $0.5 \mathrm{~m}^{2}$ each, which were suspended above the forest floor. The collected litter was air dried, sorted, and weighed.

The weight of herbs and grasses annually returned to the soil was estimated by mapping the August vegetation of the whole area in six density classes. In each class three areas of $1 \mathrm{~m}^{2}$ each were harvested and the air-dry weight of the vegetation was determined. Anemone nemorosa L., which disappeared before August, was measured in the same way in May.

Disapparance of fresh litter from the forest floor was determined in each type by comparing the dry weights of fresh litter from six random circular $0.5 \mathrm{~m}^{2}$ areas in December with the remainder of this litter before the next leaf fall in September. More detailed observation on the disappearance of litter was made by bimonthly weighing, in the field, of the fresh litter from three previously cleaned $1 \mathrm{~m}^{2}$ quadrats in each type. About 10 per cent of each sample was taken to the laboratory, analyzed for botanical composition and moisture content, and returned to the field.

Decomposition of cellulose was measured by the weight loss of three pieces of filter paper $(4 \times 4 \mathrm{~cm}$, about $0.4 \mathrm{~g}$ each) kept between litter and mineral soil for 6 to 8 weeks. Each piece was wrapped in one layer of 90gauge nylon mesh to exclude most faunal elements.

Decomposition of lignified tissue was measured by the loss of weight of six sticks $(10 \times 0.5 \times 0.5 \mathrm{~cm}$, about $0.6 \mathrm{~g}$ each) of lime wood (Tilia sp.) kept vertically in the mineral soil for 6 to 8 weeks. The cellulose content of oak leaves was determined by the difference in carbohydrates, before and after treatment of the material with $75 \% \mathrm{H}_{2} \mathrm{SO}_{4}$, by the anthrone method ${ }^{8}$. The lignin content of oak leaves was determined by the glycocollic acid method ${ }^{6}$.

Carbon dioxide was determined by drawing soil air from permanent glass frameworks $(65 \times 15 \times 4 \mathrm{~cm}$ inserted $2 \mathrm{~cm}$ into the soil) with a batteryoperated pump at a rate of $22 \mathrm{l} / \mathrm{h}$. During suction an airtight glass lid covered the frame. After an initial pumping period of 30 minutes which allowed for equilibration, the air was passed for two runs of $1 \mathrm{~h}$ each through three washbottles, each containing $8 \mathrm{ml}$ of $0.2 \mathrm{~N} \mathrm{Ba}(\mathrm{OH})_{2}$. The neutralized $\mathrm{Ba}(\mathrm{OH})_{2}$ was determined titrimetrically with $0.895 \mathrm{~N}$ oxalic acid. 
The following determinations of the microflora of the soil were made: all mushrooms appearing in the area were collected and identified, mycelium concentration was measured by the soil-suspension slide method ${ }^{10}$, mycelium growth was determined on five cholodny slides 1 left for 7 days between litter and mineral soil, fungal plate counts were made by enumerating fungal propagules developing from soil suspensions on peptone-dextrose agar containing $33 \mathrm{ppm}$ of bengal rose and $30 \mathrm{ppm}$ of streptomycin to suppress bacterial growth, bacteria and actinomycetes were counted on nutrientagar plates. Soil for plate counts and soil-suspension slides was sampled in both forest-floor types by taking ten soil cores, $2 \mathrm{~cm}^{3}$ each, from the surface of the mineral soil.

The litter and soil fauna were determined by bimonthly extractions of eighteen litter and eighteen soil samples, $1 \mathrm{dm}^{2}$ each, on berlese funnels. The soil samples were taken from the top $5 \mathrm{~cm}$. The earthworm population was determined by monthly collections from a $\frac{1}{2} \mathrm{~m}^{2}$ area, of all worms which emerged from their burrows while the soil was vibrated for at least 5 minutes with a manure fork. In each forest-floor type each time seven areas were sampled.

Air temperatures and precipitation in the open field were obtained from a station of the Royal Dutch Institute for Meteorology (KNMI), $8 \mathrm{~km}$ north of the experimental area. Soil temperatures between litter and mineral soil in the forest were recorded with a thermograph. Precipitation under the tree canopy was measured with a rain gauge. Moisture content of the litter was determined every 2 weeks from eight $1-\mathrm{dm}^{2}$ samples from each forest-floor type. Moisture content of the mineral soil was determined weekly in both types from five 10-ml cores from the top $2 \mathrm{~cm}$.

\section{RESULTS}

\section{Litter production}

The total amount of litter falling from trees and shrubs did not differ greatly in mull and mor (Fig. 1). The mean annual litter production in the two types, based on the measurements of the leaf fall in 1956 up to and including 1959 was $329 \mathrm{~g}$ and $356 \mathrm{~g}$ respectively. The greater part of the litter consisted of leaves (73 to 79 per cent, depending on type and year). The other part, twigs, seeds, fruits, insect droppings, etc., deserve attention as part of the general budget of organic matter but was excluded from this study. The total amount of leaves shed in the mull type was much smaller in the extremely dry and warm year 1959 than in 1958. This was due to the fact that alder, birch, and poplar produced in 1959 only 58,61, and 79 per cent resp. of the amount in 1958. The difference in the amount of fresh litter was less pro- 
nounced in the mor, due to the dominance of oak, which produced only some percents less. The leaf fall for each of the four main species in the mull type had a characteristic pattern (Fig. 2). Alder showed two peaks, one in July (green leaves) and one in October (brown leaves). Birch fell in August, September, and

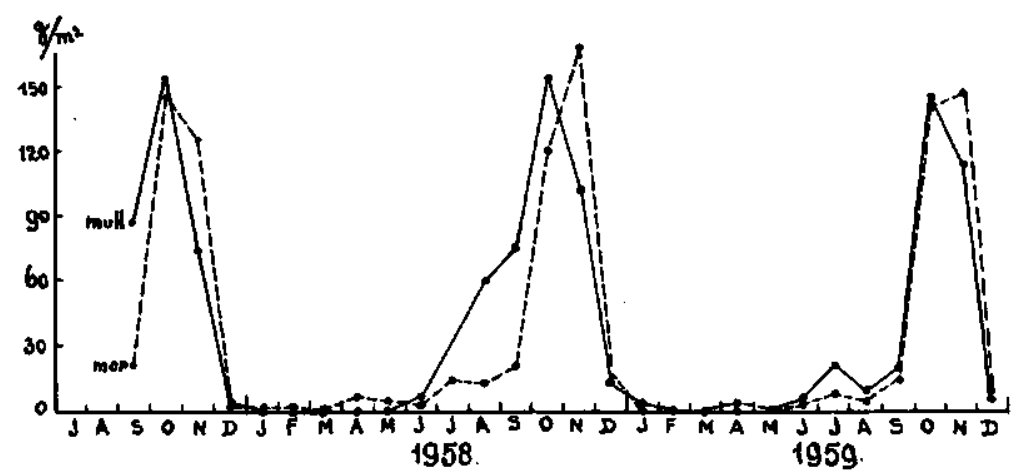

Fig. 1. Total tree litter production in mull and mor.

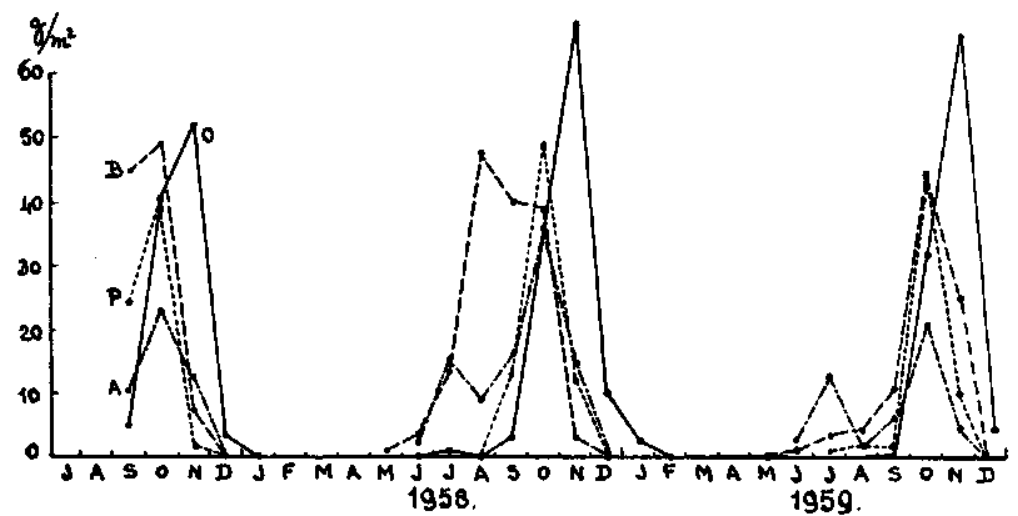

Fig. 2. Litter production of the main species in mull. $0=$ oak, $B=$ birch, $\mathrm{P}=$ poplar, $\mathrm{A}=$ alder.

October, poplar in October, and oak in November. The dry summer of 1959 caused a delay in the leaf fall especially of birch and poplar leaves. In a mixed stand, as in the mull type, this sequence of litter fall determines the structural composition of the litter layer. Dry weight of the herbs and grasses added annually to the forest floor varied from 10 to $200 \mathrm{~g} / \mathrm{m}^{2}$. The mean values for the mor and the calcareous mull were 14 and $83 \mathrm{~g} / \mathrm{m}^{2}$, respectively. 


\section{Breakdown}

The rate of disappearance of litter was high in 1956 and 1957. In both types less of the previous year's litter remained in September 1957 than in December 1956 (Fig. 3). The total amounts of litter which disappeared in both types were about $400 \mathrm{~g} / \mathrm{m}^{2}$. From

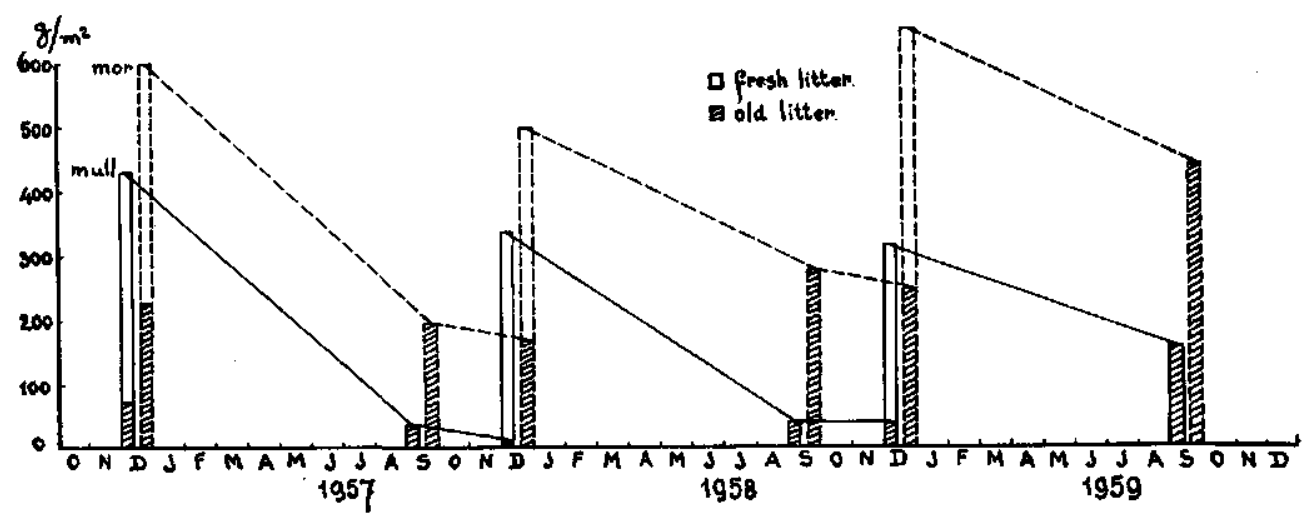

Fig. 3. Rate of disappearance of litter in mull and mor.

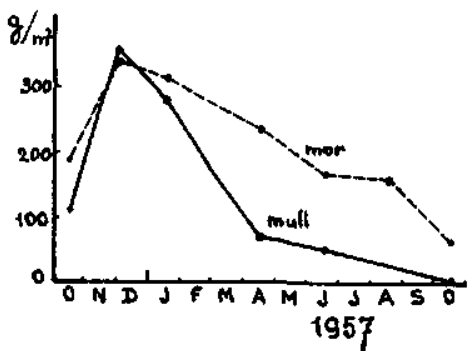

Fig. 4. Amount of litter on a cleaned surface in mull and mor.

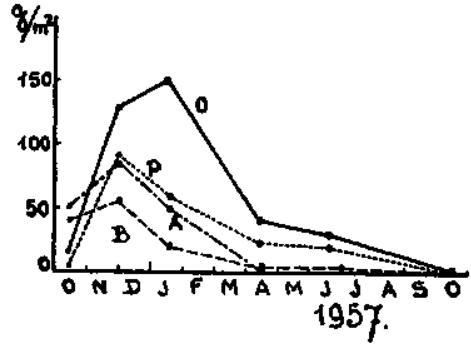

Fig. 5. Amount of fresh oak (O), birch (B), poplar (P), and alder litter (A) in mull.

December 1957 until September 1958 these amounts were 300 and $200 \mathrm{~g} / \mathrm{m}^{2}$ for mull and mor respectively, and consequently, especially in the mor, the weight of remnants of old litter was much higher than that in December of the preceding year. In the dry year 1959, the decomposition was even slower than in $1958 \mathrm{viz} 150 \mathrm{~g} / \mathrm{m}^{2}$ in the mull and $200 \mathrm{~g} / \mathrm{m}^{2}$ in the mor. This resulted in a net accumulation of litter in both mull and mor. The disappearance of the litter which fell in autumn 1956 is represented in Figure 4. During 


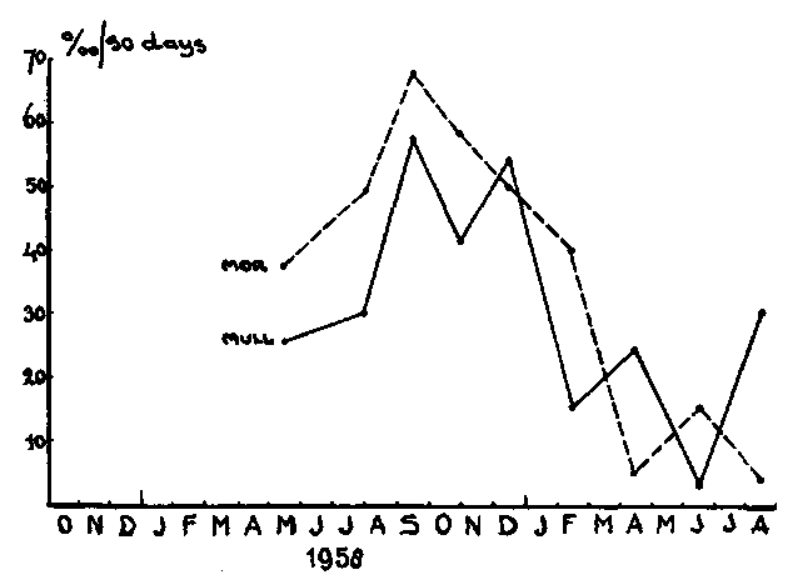

Fig. 6. Loss of weight of filter paper in mull (- - ) and mor $(---)$.

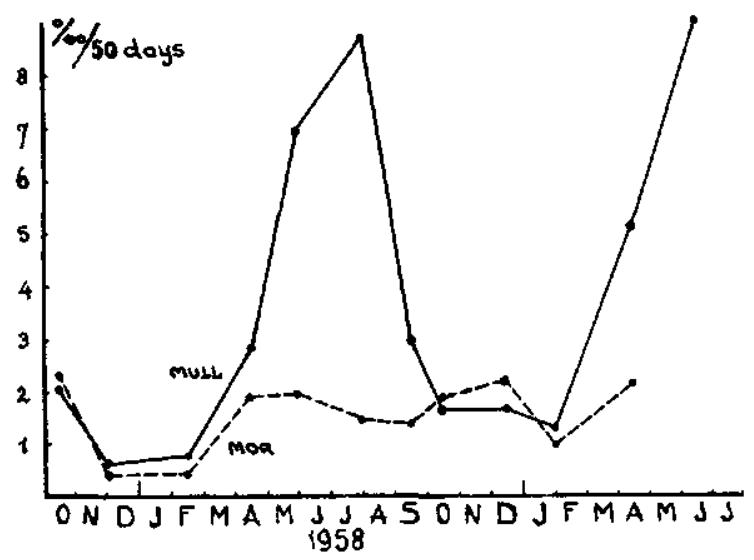

Fig. 7. J.oss of weight of wooden sticks in mull and mor.

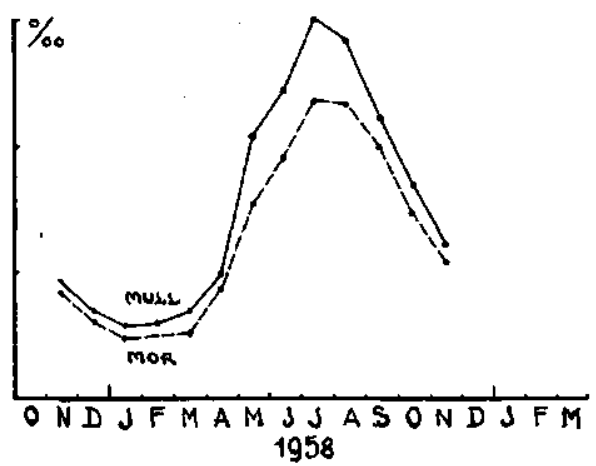

Fig. 8. Concentration of $\mathrm{CO}_{2}$ in soil air in mull and mor. 
the first 4 months the decrease of litter was very rapid in the mull type and slow in the mor. The reverse was the case in the remaining part of the year. The rates of decrease in 1957 of the main litter species in the mull type are given in Figure 5. Birch and alder disappeared more quickly than did oak and poplar.

In both mull and mor the loss of weight of filter paper was much higher than that of lignified tissue (Figs. 6 and 7). Rates of disappearance of the paper reached maxima in the fall and were in general somewhat higher in mor than in mull. The rate of disappearance of wood in mull showed a maximum in summer and a minimum in winter. In mor this rate fluctuated less with lowest values in winter. Figure 9 shows that in fresh oak litter from mull

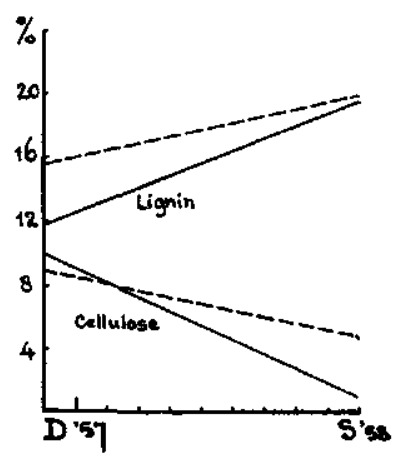

Fig. 9. Lignin and cellulose content in oakleaves fallen in 1957. mull, - - - mor.

there was more cellulose and less lignin than in oak litter from mor. The decrease of the cellulose content and consequently the relative increase of the lignin content in oak leaves from mull was larger than in oak leaves from mor. The concentration of $\mathrm{CO}_{2}$ in the soil air was accepted as an indication of over-all microbial activity because carbon dioxide is the main end product of aerobic decomposition. Monthly averages of the measurements of $\mathrm{CO}_{2}$ concentrations were highest in summer (Fig. 8). There was consistently more $\mathrm{CO}_{2}$ in mull than in mor.

\section{Biota}

From Figures 10 to 13 it appears that all measures of the fungus flora reached higher values in mor than in mull, whereas numbers of bacteria and actinomycetes were higher in mull. Development 


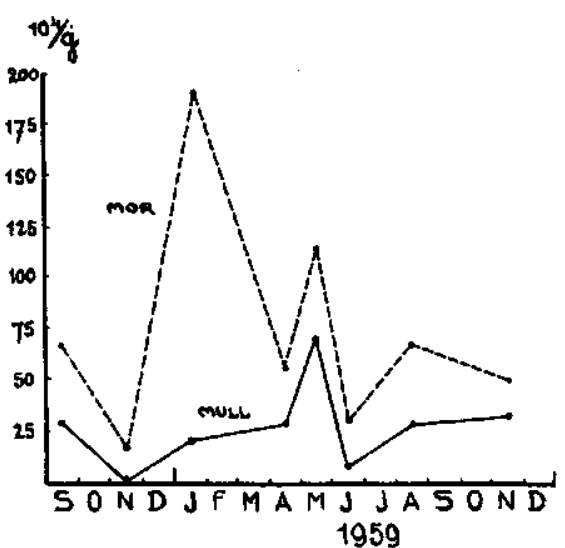

Fig. 10. Plate counts of fungi from mineral soil in mull (- $\longrightarrow$ ) and mor $(--)$.

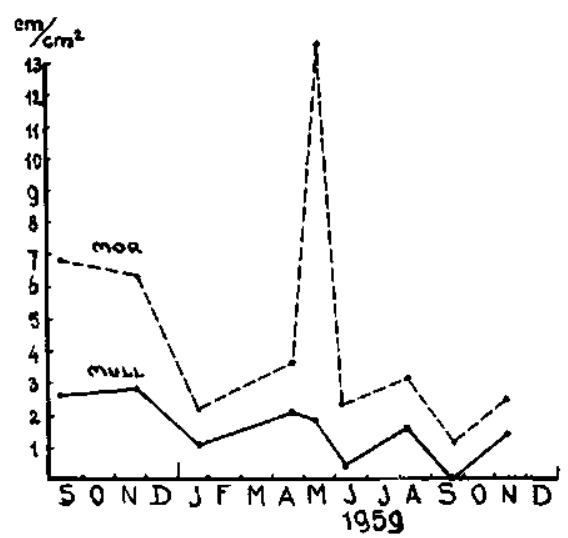

Fig. 11. Mycelium development on cholodny slides in mull and mor.

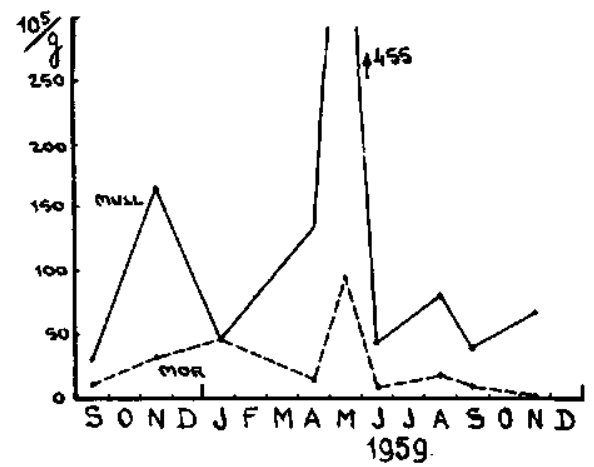

Fig. 12. Plate counts of bacteria and actinomycetes from mineral soil in mull and mor. 
of mycelium and bacteria reached a peak in spring and a low level in winter and summer. Mycelium concentration and plate counts of fungi reached maximum values in winter, whereas maximum numbers of mushroom species occurred in the fall. Mycelium concentration showed one cycle annually with maxima in winter and minima in summer.

The density of some of the most important litter feeding insects in different seasons shows a definite decrease in summer (Figs. 14 and 15). The only earthworm species, frequently caught by vibration, was Lumbricus rubellus Hoffm., the catches of which are given in Fig. 16. In both forest types captures of this species decreased in spring and increased in autumn. The density was always higher in mull than in mor. In the dry year, 1959, the activity of this surface species was very low.

\section{Seasonal fluctuations}

\section{DISCUSSION}

The detailed observations on the biota and their activities for at least 13 months make it possible to construct a picture of the mechanism of the litter breakdown from one leaf fall to the next.

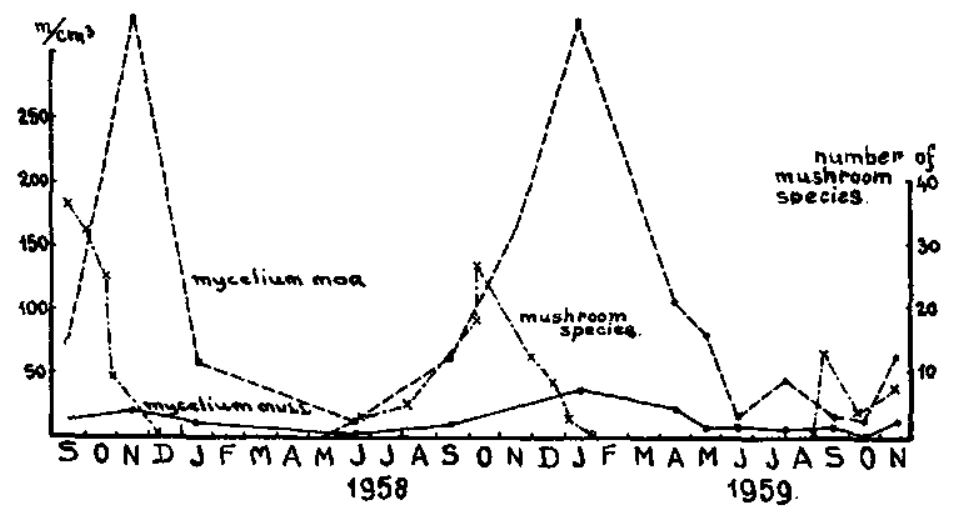

Fig. 13. Mycelium concentration in mineral soil in mull (_....) and mor $(--)$ and total number of mushroom species.

The maximum litter fall occurred in October-November (Fig. 1) when temperatures were still about $10^{\circ} \mathrm{C}$ (Fig. 17), mycelial growth on the cholodny slides was rapid (Fig. 11), mushrooms appeared in maximum numbers and the accumulation of mycelium was underway (Fig. 13). Bacteria multiplied rapidly ${ }^{10}$. Their numbers 
in the top $2 \mathrm{~cm}$ of the mineral soil were high in November (Fig. 12). The loss of weight of wooden sticks in the soil (Fig. 7) and the $\mathrm{CO}_{2}$ production (Fig. 8) declined rapidly under the influence of decreasing temperatures.

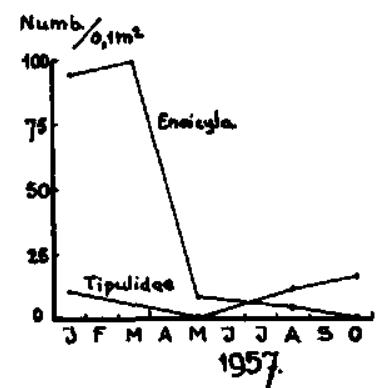

Fig. 14. Density of some saprophagous insect larvae in mull.

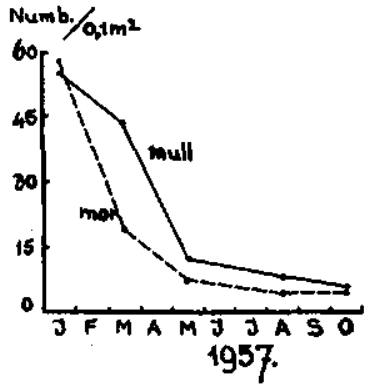

Fig. 15. Density of Nematoceralarvae (excl. Tipulidae) in mull (--) and mor (-- -).

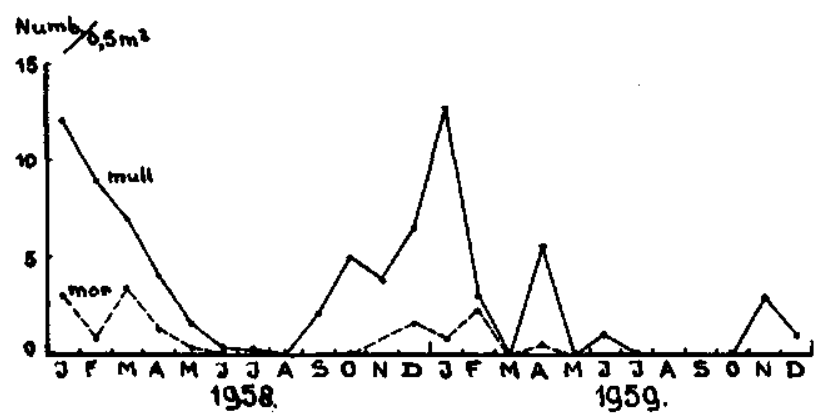

Fig. 16. Numbers of Lumbricus rubellus, activated by shaking the soil.

In December and January, mycelium (Fig. 13) and the concentration of fungal propagules (Fig. 10) increased to reach a maximum in January. From then on, all microbial activity was low, presumably because of low temperatures. Nevertheless, during the first 4 months of the year the amount of litter in the mull decreased at a relatively rapid rate (Fig. 4). This reduction may be caused by leaching, by the superficial attack by great numbers of enchytraeids which move on the wet leaves and by larger burrowing saprophagous animals, like nematocera larvae (Tipulids and Bibionids), the earthworm Lumbricus rubellus Hoffm. and several species of slugs and snails. The larvae of the caddis fly Enoicyla 
pusilla Burm. was very numerous in 1957 and took an active part in the desintigration of the litter ${ }^{4}$ (Figs. 14, 15).

With rising temperatures in May bacterial and fungal numbers and mycelium growth increased but animal numbers decreased. The decomposition of cellulose and wood increased. This is reflected in the increasing $\mathrm{CO}_{2}$ content of the soil atmosphere. Often in late May a dry period occurred and microflora and fauna minimized their activity in and also directly under the litter. In the mineral soil which was still moist, the decomposition of wood and the production of carbon dioxide by micro-organisms and plant roots

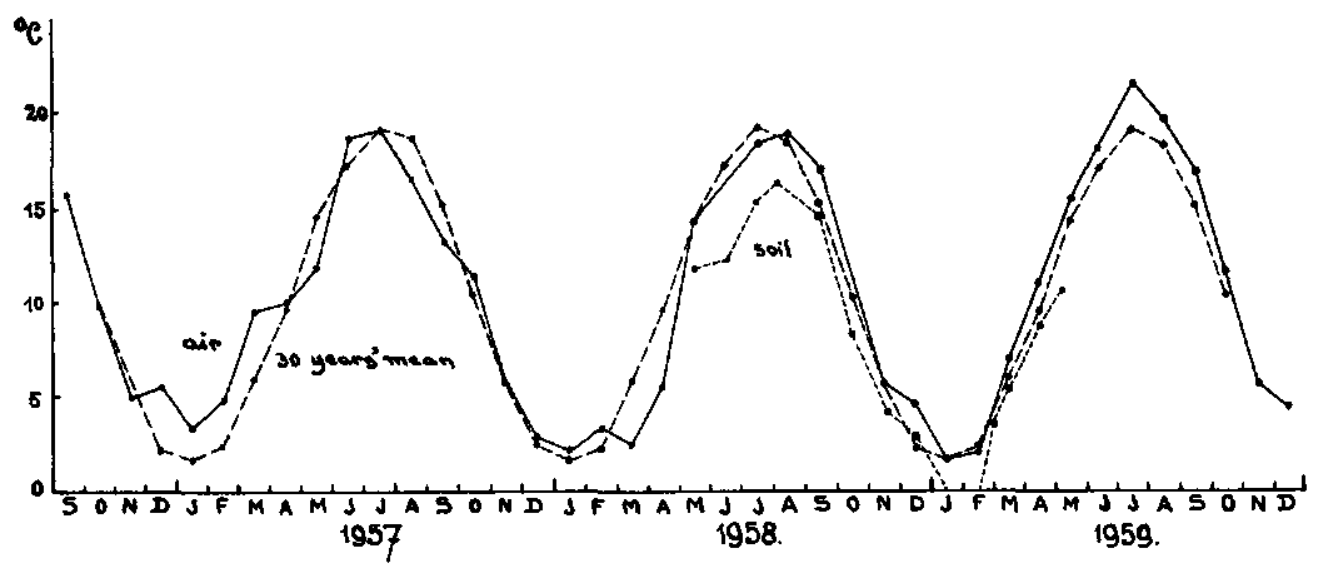

Fig. 17. Monthly averages of air temperature, soil temperature and the 30 year's mean of air temperature.

increased with rising temperatures. Summer rains, usually starting in late July or August, caused maxima in all microbial activities and an increase in animal activities. Thus the new leaf fall met an active population in the soil. In the mull the decomposition of filter paper strips just below the litter layer showed a maximum in September (Fig. 6). This possibly was caused by leachate from early fallen fresh litter which supplied easily decomposable nitrogeneous substances and prevented desiccation.

These observations emphasize the overriding influences of seasonal changes in temperature and moisture on the decomposition process in the forest floor. In general, high temperature and favourable moisture condition stimulate populations, their activities, and the resultant $\mathrm{CO}_{2}$ production. In the case of the activity of 
larger saprophagous animals and mycelium accumulation, other mechanisms prevail. The previous observations also indicate the difference in effect of the seasonal climatic changes in the different layers. In the deeper soil, $\mathrm{CO}_{2}$ production and decay of wood were strictly controlled by temperature, whereas in the top $2 \mathrm{~cm}$ decomposition was governed both by temperature and moisture, as was displayed by microbial populations and growth.

\section{Mull and mor}

In general the fluctuations in numbers of organisms, breakdown rates, and $\mathrm{CO}_{2}$ production were synchronous in mull and mor. This synchronism points to a similar influence of meteorological conditions in both mull and mor. The levels of these fluctuations, however, were different. Numbers, growth, and accumulation of fungi were constantly higher in mor than in mull, whereas the numbers of bacteria and actinomycetes were higher in mull (Figs. 10 to 13). The numbers of the larger litter-feeding animals (snails, earthworms, millipedes, isopoda, and insect larvae) were much higher in calcareous mull than in mor, but microarthropods (mites and springtails) were consistently more numerous in mor 23 . Due to the activity of the larger litter-feeding animals the litter in the calcareous mull disappeared quickly. In 1957, at the beginning of the dry period in April, only about 20 per cent of the total amount of litter which fell in 1956 remained (Fig. 4). By then about 70 per cent of the corresponding litter in the mor was still present. The small amount of resistant litter fragments in the mull decreased slowly after that, but in the mor the decrease continued at a constant rate.

The decomposition of cellulose (Fig. 6) was about equal in mull and mor. The loss of weight of wooden sticks (Fig. 7), however, showed quite different curves for the two types; the high peaks in decomposition rate from June until August in mull were absent in mor.

Warburg experiments established that litter extract added to undisturbed soil was broken down twice as fast in mull as in mor. This correlates well with the higher concentration of carbon dioxide, the more rapid loss of weight of wooden sticks, and the faster breakdown of cellulose in oak leaves in mull. According to Went 9 who worked in the same forest, decomposition of cellophane strips 
in the mineral soil was consistently faster in calcareous mull than in mor. In contrast we found that loss of weight from filter paper strips on top of the mineral soil was more rapid in mor than in mull. The relatively slow decomposition of the paper strips in the mull may have been caused by its frequent desiccation. The influence of moisture also was demonstrated by the difference of the loss of weight of filter paper in calcareous mull and mor during May, June, and July, 1958, and in the same period in 1959 (Fig. 6). Precipitation during those periods was 250 and $110 \mathrm{~mm}$, respectively (Fig. 18).

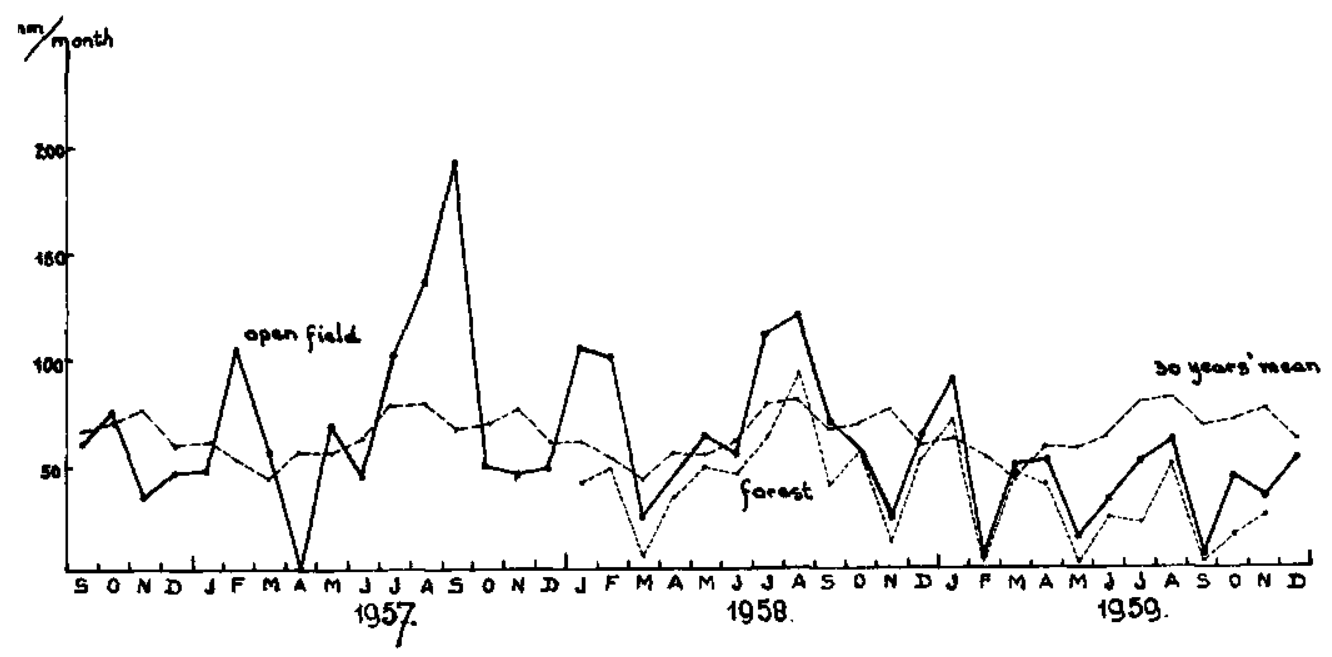

Fig. 18. Monthly rainfall in open field and forest and the 30 year's mean of rainfall in open field.

The mean annual leaf fall in mull and mor was only slightly different (see p. 297). However, there was a qualitative difference, as in the mull the $\mathrm{C} / \mathrm{N}$ of all fresh litter was 27.8 as compared to 33.2 in mor. This difference was mainly due to the presence of a profuse ground cover and of alder in the mull. In addition to this oak litter in mull consisted mainly of shadow leaves and in mor mainly of sun leaves. Sun and shadow leaves do not only differ in lignin content (19.4 and 15.9 per cent resp.) but also in form and structure which resulted in a more rapid attack of the shadow leaves by soil animals ${ }^{2}$. There was also a difference in the time of litter fall as litter fell earlier in mull than in mor. At last it must 
be mentioned that the evaporation above the litter in mor was twice as high. This was caused by a higher temperature and a lower vapour pressure inducing a higher saturation deficit. Especially in spring the litter began in desiccating more rapidly in mor and so the circumstances for animal attack are worse. These differences inducing greater animal activity during autumn, winter and spring with subsequent increased microbial decomposition ${ }^{4}$ in the mull caused the litter to disappear initially more rapidly in this type. Consequently, during the summer only a thin, discontinuous litter layer remained in the mull leaving the mineral soil subject to desiccation which interrupted animal and microbial activity. In the mor litter breakdown was more constant throughout the year (Figs. 4 and 7).

\section{Annual differences}

Comparison of the microbial population and its activity in different years showed differences in phase as well as in level. In 1958, winter and spring temperatures were lower (Fig. 17) and summer was drier than in 1957 (Fig. 18). Consequently, decay of the litter in both mull and mor was slower in 1958 (Fig. 3). This led to a considerably larger amount of undecayed litter in the mor at the end of the season of 1958. In 1957 most of the litter in the mull had disappeared from the surface by May. In 1958 breakdown by animals in winter and spring was slower than in 1957 and was taken over by micro-organisms until the end of the season. By then only a small amount of litter remained.

Precipitation was extremely low in 1959: $512 \mathrm{~mm}$ against $825 \mathrm{~mm}$ in 1958 and 907 in 1957. This resulted in litter accumulation, both in mull and mor (Fig. 3).

The difference between 1957 and 1958 in appearance of mushrooms and in the number of species present (Fig. 13) were also due to differences in precipitation. In mid-August 1957, summer rains fell after a rather dry spring. As a result an abundant flora of mushrooms thrived, which lasted until the end of September. In 1958, however, with relatively dry weather in August and September, mushrooms appeared in October in smaller numbers representing fewer species than in the previous year. This shift in phase can also be seen in the curve representing concentration of mycelium (Fig. 13). 
The influence of drought was illustrated during the summer of 1959 when the moisture content in mull and mor dropped below the wilting point (Fig. 19). Consequently, the values obtained for mycelium growth, mycelial concentration, plate counts of fungi as well as bacteria and actinomycetes, numbers and species of mushrooms, cellulose decomposition, $\mathrm{CO}_{2}$ production, animal

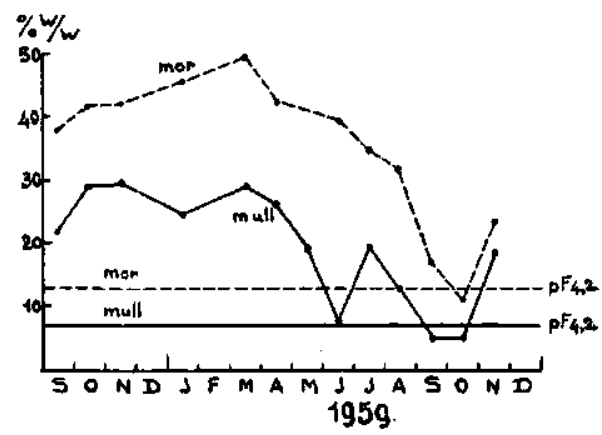

Fig. 19. Monthly averages of moisture content in soil in mull and mor.

activity and disappearance of litter were lower in 1959 than in 1958. After adequate rainfall in November 1959, the microbial population increased again.

The annual differences in litter breakdown in both mull and mor were caused mainly by differences in amount and distribution of rainfall and to a lesser extent by variations in temperature. The mull was more vulnerable to desiccation to the wilting point than mor, especially in the summer when the litter layer in mull was thin and discontinuous. Rapid desiccation and the dominance of surface-rooting species in the mull provided a built-in regulating mechanism against litter accumulation which produced less litter during times of slow decomposition. In the mor type the deeprooting oak dominated, and drought did not influence litter production. Here a full year of breakdown was required to balance litter fall. Slightly unfavourable wether conditions would cause litter accumulation. In the mull only extremely unfavourable conditions can cause litter accumulation, which will be eliminated during the next more favourable years.

Topographic and climatic factors, the composition of fresh litter, and the biota governed the rate of litter disappearance whereas the 
latter two factors also determined the qualitative aspects of decomposition. The microflora and the soil fauna appeared to be determined primarily by the composition of the litter, that is by the botancial composition of the vegetation, by the rate of desiccation of the litter layer, and locally by the presence of lime $2 \mathbf{1 0}$. Minderman ${ }^{7}$ indicated a strong correlation between forest-floor type and water regime in the same stand. It then seems plausible to state that in this area differences in depth of the water table, water-holding capacity and the content of lime in the soil caused differences in vegetation and subsequent differences in microflora and litter-feeding soil fauna, and ultimately in forest-floor type. The correlation between forest-floor type and vegetation in this area has been established and will be dealt with in a subsequent paper.

\section{SUMMARY}

Production and breakdown of forest litter in a single stand were compared in different forest-floor types (mull and mor), during several years. Litter production was almost equal in both types. In the extremely dry year 1959 less litter was produced in the mull, due to a strong desiccation and surfacerooting species. In the mor, the litter production was less influenced, thanks to lesser desiccation of the soil and the deeper rooting oaks. The litter in the mull fell earlier and had a more favorable $\mathrm{C} / \mathrm{N}$ for biological decomposition (27.8) than in mor (33.2).

The fluctuations of density and activity of the floral and faunal elements taking part in the breakdown of litter in mull were generally synchronous with those in mor. Between these two types, however, differences in level of density and activity of the biota existed. In general, biological activities and carbon dioxide concentrations in the soil were higher in calcareous mull than in mor. In the calcareous mull larger litter-feeding animals, bacteria, and actinomycetes dominated as a result of the higher air humidity, the presence of calcium carbonate and the larger amounts of protein and easily decomposable carbohydrates in the mull litter. In the mor, where the litter contained more lignin and cellulose and less protein, fungi and microarthropods were most numerous. The larger saprophagous animals were mostly active from October to April. This caused a rapid disappearance of the freshly fallen litter in the calcareous mull, followed by incorporation of the breakdown products into the soil. This breakdown was mainly mechanical and thus did not yield high carbon dioxide concentrations in the soil. As temperatures rose, the microbiological populations and their activities increased, depending on moisture conditions. In the calcareous mull the annual breakdown of shed litter was almost completed in half a year. In 
mor this breakdown continued through a full year. Unfavourable weather conditions, as in 1958, retarded decomposition, prolonged the period required for breakdown in the calcareous mull, and caused accumulation of litter in the mor. Extreme drought in 1959 caused a net accumulation even in the calcareous mull. In an acid mull type the values obtained for practically all factors and processes studied in the calcareous mull and the mor occupied an intermediate position. It is concluded that differences in forest-floor type in the area of the present work were primarily conditioned by edaphic factors which influence vegetation, litter composition, air humidity, soil microflora and fauna, and ultimately forest-floor type.

Received August 4, 1960. Revised paper October 25, 1961

\section{LITERATURE CITED}

1 Cholodny, N., Uber eine neue Methode zur Untersuchung der Bodenmicroflora. Arch. f. Mikrobiol. 1, 610-652 (1930).

2 Drift, J. van der, Oorzaken en gevolg van verschillen in bodemfauna in verschillende typen eikenbos. Nederl. Bosbouwk. Tijdschr. 33(4), 90-108 (1961).

3 Drift, $J$. van der, The soil fauna in an oakwood with different types of humus formation (in press).

4 Drift, J. van der, and Witkamp, M., The significance of the breakdown of oak litter by Enoicyla pusilta. Burm. Arch. Neerl. de Zool. 13, 486-492 (1960).

$5 \mathrm{H}$ andley, W. R. C., Mull and mor formation in relation to forest soils. Forestry Comm. Bull, 23, 1-115 (1954).

6 Holmberg, B., Lignin-Untersuchungen, XI Mitt.: Fichtenholz and MercaptoSauren. Ber. deut. chem. Ges. 69, 115-119 (1936).

7 Minderman, G., Mull and mor in relation to the water regime of a forest soil. Plant and Soil 13, 1-27 (1960).

8 Morris, D. L., Quantitative determination of carbohydrates with Dreywood's anthrone reagent. Science 107, 254-255 (1948).

9 Went, J. C., Cellophane as a medium to study the cellulose decomposition in forest soils. Acta Botan. Neerl. 8, 490-491 (1959).

10 Witk a mp, M., Seasonal fluctuations of the fungus-flora in mull and mor of an oak forest. Thesis Wageningen. Meded. nr. 46 Inst. Toegepast Biol. Onderz. in de Natuur (1960). 
